\title{
TOOLS FOR LOCAL GOVERNMENTS TO PROTECT AND FAVOR SUSTAINABLE CONSERVATION AND (RE-) USE OF EARTHEN HERITAGE IN AUVERGNE RHÔNE ALPES REGION, FRANCE
}

\author{
B. Rakotomamonjy ${ }^{1}$, T. Joffroy ${ }^{1}$ \\ ${ }^{1}$ CRAterre team of AE\&CC research unit (Labex), Ecole Nationale Supérieure d'Architecture de Grenoble (ENSAG), Univ. \\ Grenoble Alpes, France - bakonirina.rakotomamonjy@grenoble.archi.fr
}

Commission II - WG II/8

\begin{abstract}
KEY WORDS: Local government, Methodology, Participatory Approach, Conservation, Rehabilitation, Contemporary earthen
\end{abstract} architecture, Awareness

\begin{abstract}
:
In 2018, a guide to the attention of the local governments has been published by CRAterre, entitled « Guide à destination des collectivités territoriales pour la réhabilitation et la valorisation du bâti en pisé ». It is one of the main results of a four years projects funded by the Auvergne-Rhône-Alpes Region on traditional rammed earth buildings that included researches on the geographical repartition, the variety of typologies, the state of conservation and the potential for sustainable development in the Region. It contains an organised series of recommendations and tools that could be implemented for the identification and revitalisation of rammed-earth vernacular heritage at a local level. These have been prepared as a response to the overall assessment made which revealed high potential and responsibility on the part of local governments to protect this heritage, promote continuity of its uses and to disseminate good rehabilitation practices. This paper presents the participative approach adopted for both the research process and the elaboration of the guide. That resulted in developing some original contents to the attention of the variety of groups of stakeholders. These were tested in the field and gradually improved taking into account the interactions with the local politicians and actors. The paper also covers a reflection on further dissemination of the knowledge developed for applications at a wider scale.
\end{abstract}

\section{INTRODUCTION}

First published studies on earthen architecture in the Auvergne-Rhône-Alpes Region date back from the 70s. The first attempts for undertaking formal inventories were made in the beginning of the 80s (Bertin, Clemençon, 1983; CAUE de l'Ain, 1985) and covered few of the areas that had been identified. With a growing interest in this vernacular rammed earth process, locally called Pisé, it became clear that the concerned area was very large, actually covering most of the glacial valleys originated from both the Alps and the MassifCentral. Observations also led to the knowledge that this heritage was covering many types of buildings (houses, barns, schools, public buildings, hospitals, churches, industrial buildings...). In addition, based on an inventory at a small scale, an estimate had been made which led to an approximate number of buildings made with earth of around 1000000 units. Thus, the conclusion by that time could just be that, in spite of the efforts made, earthen architecture had been less documented and less known in our territories than other vernacular typologies (Guillaud, 2014).

In 2015, a four years research project was launched with funding allocated by the Région entitled "Promotion of the rammed earth heritage in Auvergne-Rhône-Alpes Region". In addition to covering several technical aspects (condition surveys and restauration / rehabilitation techniques), this project had an inventory component. It confirmed the predominance of rammed earth heritage in the Region but also questioned the issue of how an inventory at such a geographical scale could be addressed. Besides that, it aimed also to study the potential of that heritage and to assess the pertinence of embarking in a policy on regional scale for valuing it.
This research-action project resulted in defining some original strategies learned from the adopted participative approach. In that respect, it involved several pilot activities carried out on site with local politicians in charge of culture or heritage as well as with representatives of associations more or less specialised in heritage preservation and conservation.

\section{THE RESEARCH PROJECT}

\subsection{General framework of the research project}

The research project entitled "Promotion of the rammed earth heritage in Auvergne-Rhône-Alpes Region" was proposed within an overall "Development Contract" presented to the Region by "Isère, Porte des Alpes", an organisation gathering together several local governments located at the northern side of the Isère Department.

It had been set up as a follow-up project to an earlier contract funded by the Region to facilitate local development, which already had a component centred on the Pisé tradition.

The project was co-coordinated by CRAterre and AE\&CC 1 research unit at Ecole Nationale Supérieure d'Architecture de Grenoble. It was implemented in 4 years, starting in 2015 and ending in 2018. It was planned and developed taking into account the overall territory of the Region, with however a focus on the "Isère, Porte des Alpes" area and specific pilot activities carried-out in some volunteer local governments.

Architecture, Environnement et Cultures Constructives is a research unit under the administrative supervision of Ecole nationale supérieure d'architecture de Grenoble and the French ministry of culture. 
The research objectives of this participatory project were to:

- find-out how a better quantitative and qualitative knowledge of the rammed earth architectural heritage in Auvergne-Rhône-Alpes Region could be elaborated;

- understand its values and the organization of the stakeholders that make it a living heritage;

- evaluate the existing promotion policies / strategies / tools around this heritage, with the view of a potential diffusion of good practices in other concerned territories.

\subsection{Project methodology}

The project was implemented in a participative manner involving a large variety of stakeholders: individuals and organizations, directly or indirectly concerned. A strong willingness was to take into account the existing local dynamics whether they be private, professional or institutional, and to study the potential to disseminate, feed and/or better articulate them.

The project mobilized thus several local authorities such as "Communauté d'Agglomeration Porte de l'Isère" and "Communauté de Communes des Balmes Dauphinoises", the Heritage House at Saint Chef, the Bourgoin-Jallieu Museum and the AGEDEN (Isère Energy Information Office).

At the departmental and regional levels, it involved the DRAC ${ }^{2}$, its unit for architecture and heritage, the Region Inventory Unit, the Heritage Department of the General Council of Isère, and local advisory bodies such as $\mathrm{CAUE}^{3}$ and $\mathrm{ANAH}^{4}$. Specialised associations (heritage) were also strongly involved, more specifically in the field activities.

Actually, the various actions carried out were an opportunity to collectively question the current situation but also to establish a dialogue and sustainable links while gathering information specific to each territory and organization for establishing technical and strategical diagnosis.

\subsection{Project activities}

The project was organised around a set of complementary activities:

Capitalisation of research on rammed earth heritage in France. This led to the update of the rich bibliography on the topic. It highlighted the fact that what had been published recently was mainly for general public awareness or purely tackling technical aspects. It made clear the lack of operational guidelines that could be used by decision makers to define strategies for a better management of the earthen heritage at the local level (the territory concerned being very wide, a centralised system would hardly be operational / efficient).

Elaboration of a full list of already gazetted architectural ensembles and sites built in Pisé. Within the French heritage system, there is a variety of labels used for protection. The most important is the national inventory of monuments that includes a main and a secondary list. Besides that, there are several additional labels, managed locally which include Architectural, Urban and Landscape Heritage Protection Area (ZPPAUP), protected historic city centres and Regional Parks.

Direction Régionale des Arts et de la Culture

Conseil en Architecture, Urbanisme et Environnement

Agence Nationale pour l'Amélioration de l'Habitat
Mapping of areas where Pisé is present. For this census, existing data were first analysed. These included studies on the vernacular architecture dating from the 20th century (Raulin, 1977; Royer, 1979); the National General Inventory (Guibaud, 2005); Local building analysis (EDF-PACT, 1985); researches focused on earthen architecture (Scarato, 1984; Bertin, Clémençon, 1983; Joffroy et al.1991; Mille, 2016; Studer, 2016).

Data were also collected in the field, online and through questionnaires sent to partners and specialists on earthen architecture.

Qualitative knowledge of the values of Pisé heritage. This study was done in a reduced territory, the "Isère, Porte des Alpes" area. In order to first identify and then characterise the rammed earth heritage, representatives of the municipalities and of cultural associations were directly involved.

After a brief presentation of the cultural values of vernacular heritage, participants were able to identify key features (monuments were identified but ensembles and private properties were also often put in light) and to discuss their values (focusing mainly on the historical and cultural values).

These series of field visits and meetings highlighted the rich history of the local heritage. This characterisation was deepened through discussions on the challenges this heritage is facing. Participants, despite a lack of technical knowledge, were clearly aware of the weaknesses and risks and the need for better information and coordinated efforts to address them efficiently.

Census of initiatives in the rehabilitation and valorisation of earthen construction. This involved the identification of initiatives and actors engaged in Pisé protection/promotion within the last decades. Because of time constraints, this research focused on projects or initiatives engaged by public and non-profit organizations. Data collection was made through an investigation within the professional networks, web research and then interviews of relevant individuals.

Data collected included: location of the actions, number per Department, typologies, time-frame and targeted public. The involvement of politicians and professionals from many public services and bodies (culture, land law, urban planning, housing, etc.) has allowed important data to be crossreferenced, particularly in the functioning of local authorities (Paccoud, 2017).

Several of the above-mentioned initiatives, those who had been implemented over a long period of time or appearing to have had a large impact, were studied in detail in order to better understand their strategic approach and the way they were put in place to reach such impacts. These experiences are presented in the guide.

The study of the legislative and administrative framework related to rehabilitation and valorisation of Pisé. The project allowed an in-depth analysis of the complex set of legal and administrative frameworks that exist in France as it has assets at national, regional and local levels. The goal was to identify the different responsibilities of government bodies that are engaged or should be engaged in the management of Pisé heritage and which role they should play for ensuring a better protection, rehabilitation and valorisation at a local level. 
That quickly led to the idea that a specifically dedicated guide would be very useful to improve the situation. In order to launch this, a series of workshops and meetings were organised in several selected local governments, allowing discussions on these issues and reflections on realistic strategies and activities to be implemented and integrated in the proposed guide.

\section{FINDINGS}

\subsection{Rammed earth construction: a predominant heritage}

The research reaffirmed that in the Auvergne-Rhône-Alpes Region, rammed earth buildings are predominant in its glacial valleys. They are largely present in $22 \%$ of the municipalities in the region, housing more than 3 million inhabitants (Figure 1).

In some villages, up to $80 \%$ of the housing have parts of their structure built with rammed earth. This inventory includes a wide variety of buildings, such as mansions, agricultural buildings, public buildings, schools, churches or industrial buildings. In towns, multi-storey buildings can be found, like in Lyon, sometimes up to six storeys high (Alex, 2012). The new established map clearly shows how important the subject of the rammed earth building is and to which extent this heritage marks the territory's identity (Paccoud, 2017), not only in the rural areas but also in the urban contexts.

Part of these buildings were easy to identify, as they were already inscribed on the existing lists of protected heritage. There are sixty-two Pisé buildings or ensembles already listed or classified as historical monuments. These historical monuments are mostly agricultural or domestic complexes.

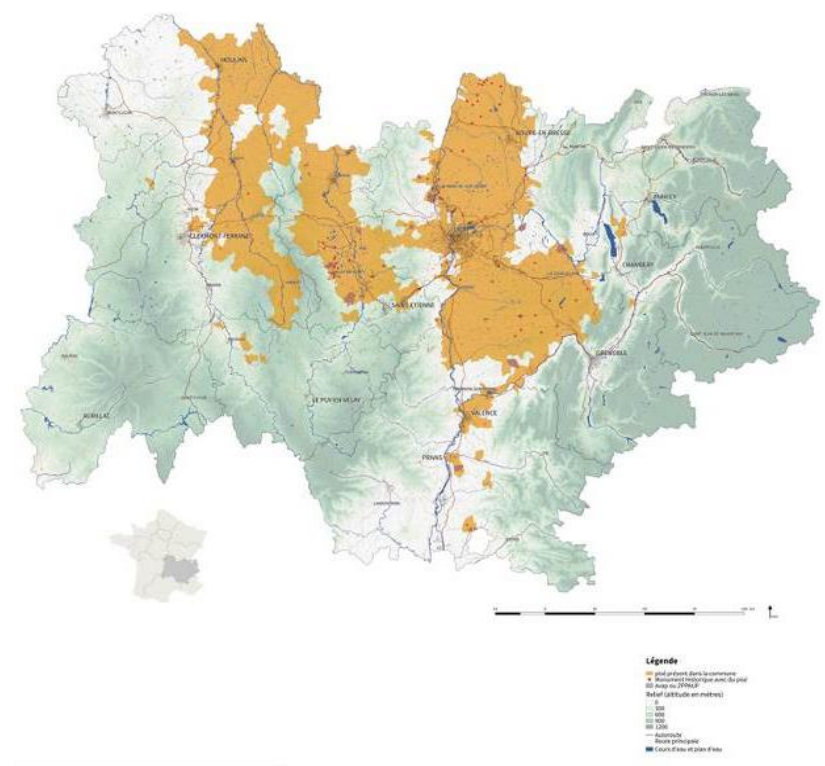

Figure 1. State of the inventory of architectures in rammed earth in 2018 @ C CRAterre 2018.

Still this census remains an on-going process as the mapping needs to be completed, in particular in the Auvergne area (west zone of the region) which, despite efforts, could not be entirely covered during the planned inspection visits.

\subsection{A growing dynamic of revitalisation of earthen construction in place for more than forty years}

The survey revealed a significant development and, moreover, an acceleration of the number of projects and initiatives focused on earthen architecture. It led to the identification of seventy-seven initiatives implemented between 1977 and 2016 (Paccoud, 2017). They are of different natures (exhibitions, conferences, visits, trainings and publication). They mostly target the general public, but some projects are addressing private sector professionals including training activities.

A series of major projects has also been identified as key milestones for the valorisation of Pisé heritage (Joffroy, 2018), those are:

The construction of the "Domaine de la Terre", collective housing buildings and associated services, carried out in particular by the OPAC of Isère and the Public Establishment of the Isle of Abeau. This settlement, whose particularity is to use mainly raw earth construction techniques, including rammed earth, was completed in 1985. This singular operation has been an extraordinary demonstration of the relevance of the use of earthen material in our contemporary society.

The yearly Festival Grains d'Isère in Villefontaine at the Grands Ateliers de l'Isle d'Abeau, financed by local governments and organized by the CRAterre-ENSAG research laboratory since almost twenty years. This festival, whose aim is to enhance and develop knowledge related to construction with earthen material, includes demonstrations, conferences, visits and workshops for various audiences (professionals, politicians, school kids' groups, house owners, etc.) (Figure 2).

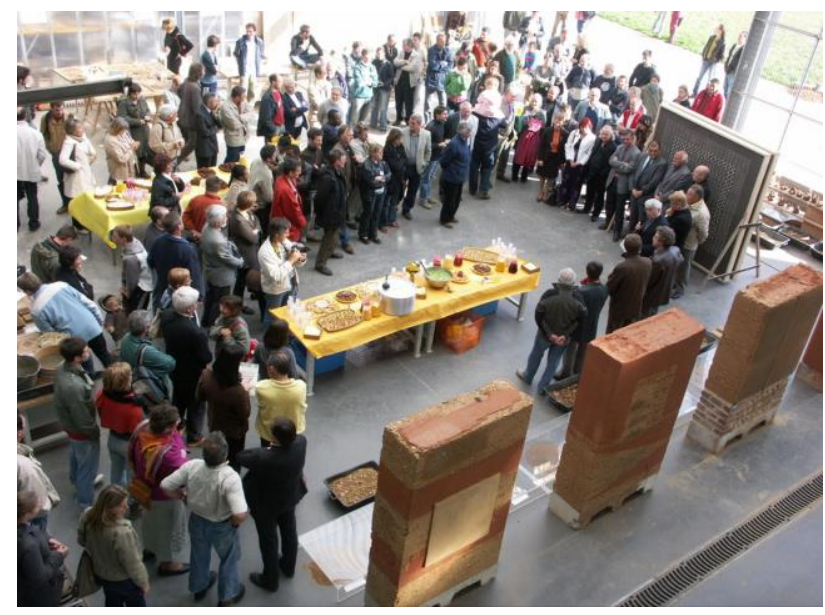

Figure 2. Inauguration of the Grains d'Isère Festival with the presence of local politicians (C) CRAterre 2012.

Demonstrative rehabilitation projects with technical and financial support of the "Isère, Porte des Alpes" local government, for example the restoration of the elevations of two buildings for the municipality of Chèzeneuve. Another example was the rehabilitation of the Porcher barn in Nivolas Vermelle ${ }^{5}$ (Le Tiec, Paccoud 2006). These projects are examples of adapted work on rammed earth buildings allowing the transmission of know-how as well as the enhancement of buildings.

https://archive.org/details/PiseH2O 
Simultaneous development of research and educational programs. Since the beginning of 2000, CRAterre research laboratory at ENSA Grenoble has developed an innovative research and educational program on the scientific properties of earth as a building material. This program led to the elaboration of two training kits:

- Grains de Bâtisseurs, with hundred scientific experiments that has also led to an exhibition presented in Paris and in several other cities in France;

- ÉlémenTerre, an educational kit valorising a selection of the experiments of Grains de Bâtisseurs.

The main interest of ÉlémenTerre is that it can be presented in several forms and be an inclusive part of an education program. In that sense, ÉlemenTerre was included in several school curriculums of the region with the support of DRAC ${ }^{6}$. From 2015 to 2018,1600 pupils in 12 schools and 2400 individuals have benefited from ÉlemenTerre. It received also a regional award in the category "know-how" in 2017. Both these tools are adapted for wide dissemination of scientific knowledge on earthen construction.

The first national award on earthen architecture has promoted contemporary earthen architecture in France in 2013. The award promoted recently built projects and encouraged building companies to engage in new uses of earth as a building material. In 2016, the first international award (Terra Award) continued this dynamic at an international level.

However, the analysis of the situation highlighted some pitfalls. First, it pointed out the need to strengthen projects for professionals, both in the private and the public sector. Secondly, it showed that the dynamic lacks legibility and unifying links, and thus wide visibility. The lack of coordination entails a repetition of similar mistakes and does not allow a proper capitalisation of the knowledge and supporting material to present them and is too often elaborated for use for a single activity.

\subsection{Pisé and competences at local governments levels}

The analysis of the legislative and administrative framework has resulted in the identification of various areas of competence of the public bodies in charge of the concerned territories that could be used efficiently to improve the preservation and rehabilitation of the Pisé heritage. These public bodies include local governments, municipalities, the departments and the Region, and moreover, the specific technical services associated with them.

Six specific areas of expertise were identified:

- Cultural heritage: foster inventory or study of heritage and the establishment of protection systems and conservation actions;

- Urbanism: take into account in planning documents and planning policies the specificities of the rammed earth heritage and ensure its protection;

- Habitat: take into account, in housing policies, the characteristics of rammed earth buildings and the needs of its inhabitants;

- Technical services: take into account the technical characteristics of the earth materials when planning and implementing works around buildings, including maintenance of networks and roads;
- Economic development: foster the development of the local building sector and the dissemination of knowledge on the restoration and new construction in rammed earth;

- Tourism: promote cultural and economic enhancement of urban and rural landscapes based on vernacular Pisé;

- Environment: value the ecological performance of the rammed earth building techniques.

\section{TOOLS}

The various results of the research project led to the production of a set of tools allowing a better management of the Pisé heritage by a variety of potential users.

All results of the project have been posted on a freely accessible web site ${ }^{7}$ presenting the description of the project, a general and specialised bibliography, the results of the inventory, the diagram of the public bodies concerned by Pisé and a first attempt of guidelines for stakeholders to better manage the rammed earth heritage.

In addition, the research project allowed the elaboration of a guide entitled "Guide à destination des collectivités territoriales pour la réhabilitation et la valorisation du bâti en pisé" (Joffroy, Rakotomamonjy, 2018). The objective of this guide is to steer the decision-makers and technicians of local governments in the glacial valleys of Auvergne-Rhone-Alpes Region in a better management of rammed earth heritage (Figure 3).

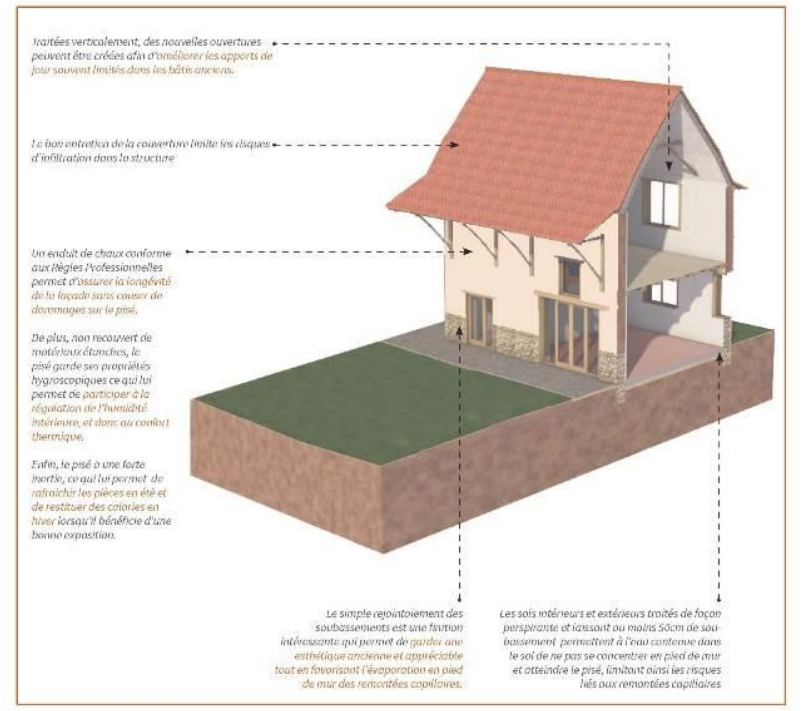

Figure 3. Drawing extracted from the guide presenting some characteristics of rammed earth vernacular heritage (C) Osmia architecture 2018.

In the first chapter of the guide an overview of the history of the development of rammed earth in the region is presented. In the second chapter the key issues to be taken into account for its proper management are explained (technical specificities, importance of its inventory, general conservation principles, key issues to consider for its re-use, key technical consideration when undertaking works in and around the rammed earth building, socio-economic aspects to consider for the revival of the rammed earth constructions). The third chapter presents the different roles that specific departments of governing bodies can play in the management of rammed earth construction. The 
fourth chapter describes the main steps to elaborate a territorial development strategy based on this strong vernacular heritage. Finally, the fifth chapter presents some large impact initiatives that could inspire decision makers.

The guide highlights the potential that this heritage offers for the development of the territories, including quality of the living environment for the inhabitants; local and sustainable economic activities to increase the attractiveness of the territory by enhancing the heritage; nourishing the cultural life of the territory around a unifying element. This guide provides arguments and moreover, proposes action paths for the various territorial services, with concrete examples on key issues to safeguard and sustain the rammed earth heritage.

\section{WAY FORWARD}

The prevalence of rammed earth in their territory is a challenge for numerous local authorities within the Auvergne-RhôneAlpes Region. Rammed earth is an issue for them, both because it constitutes a potential for local development and because it is a heritage in decay under their responsibility which they have to manage, in a way or another. Furthermore, the legal and administrative frameworks clearly mandate them to take on board this challenge, not only for the technical aspects, but also for the economic, social, cultural and environmental values this heritage carries.

\subsection{Strengthening the capacity of local authorities}

The guide is considered as useful to address the challenges faced by the competent local government services. It is also considered as a useful tool for local authorities to develop a territorial policy and to implement the actions that will lead to a better care of the old Pisé buildings, to feed the reflection and guide the definition of pertinent strategies. As a result, several local authorities have purchased it, and some even promote it in departmental and regional local authorities' meetings.

This motivated the institution responsible for the support of public authorities (National Territorial Public Service Centre CNFPT), to launch in 2018 a specific training module on earthen architecture to the attention of local authorities: politicians and technicians.

\subsection{Continuation of the census and protection of valuable heritage}

The inventory of the rammed earth heritage and its outstanding values has started but remains incomplete. Additional efforts need to be done to complete it in order to emphasize the great importance of this heritage in the region; an important step for a better protection, a valuable asset, on a local, regional or national level. This work is ongoing under the direction of the institution in charge of the regional inventory. It could take advantage of parallel initiatives launched by local authorities such as CAPI in the Nord-Isère area.

\subsection{Rammed earth: a driving force for territorial development policy}

In many parts of the world, local authorities appropriate their cultural heritage as a resource for local development with social, environmental, economic and cultural benefits. In the Auvergne-Rhône-Alpes Region, the heritage in rammed earth can be one of these strategic levers of sustainable development of the territories.
The safeguarding and enhancement of rammed earth's heritage can be a valuable sustainable territorial development policy for local authorities, due to the fact that it can contribute to struggle against urban sprawl by:

- stimulating the revitalisation of old urban centres and rural villages;

- favouring the rehabilitation of the existing built-up park;

- enhancing the attractiveness of the territory to visitors as well as economic actors and investors;

- valuing a remarkable heritage;

- fostering cultural vitality by sharing the values of this heritage through information, awareness and animation.

Pisé heritage is also likely to be a lever for the public authorities, responsible to accompany the environmental transition and so, will respond to the growing interest of people for a more environmentally friendly way of living. Its revitalisation can contribute to:

- produce a quality living environment for the inhabitants through comfortable buildings built with healthy materials adapted to contemporary ways of living;

- promote environmental sustainability by prioritizing short circuits and natural materials sectors

- sustain the development of local sectors that create nonrelocatable jobs that help to reduce energy bills and environmental footprints.

By placing Pisé within their vision of the territorial development, local authorities thus participate in the implementation of the national policy, in particular the National Commitment to the Environment Act (Law No. 2010-788 of July 12, 2010 known as Grenelle 2), the Law for Access to Housing and Renovated Urban Isis (Law No. 2014-366 of March 24, 2014 known as the ALUR Act) or the Green Growing Transition Act (Law No. 2015-992 of August 17, 2015 known as LTECV).

The various actions involved in the heritage conservation chain:

- knowledge, protection and enhancement - lay the foundation of a virtuous circle;

- knowledge of heritage promotes its preservation and stimulates the emergence of rehabilitation;

- these projects perpetuate the uses and consolidate the socio-economic sphere linked to this heritage;

- thus create the favourable conditions for a sustainable revitalisation of the rammed earth construction sector.

\subsection{Demonstratives project for setting operational methodologies}

As mentioned above, various actors are already mobilised for the promotion of earthen architecture in the territory and there is an increasing number of initiatives. However, there is a lack of coordination. If theoretical models of coordination exist, it is also through action that pertinent modus operandi can gradually be defined. In that perspective, in 2018, the CAPI local government and the School of Architecture of Grenoble DesignBuild-Lab have embarked on a pilot operation: the design and construction of a $200 \mathrm{~m} 2$ building, the Maison pour tous (House for all) in rammed earth. This project was strongly supported by the local authorities. It brought together architecture students, local inhabitants, a large number of local building companies and craftsmen and research laboratories (Figure 4). 


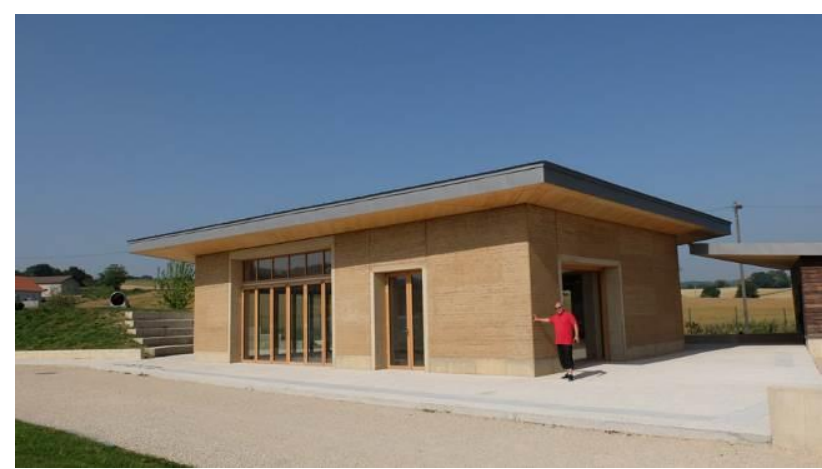

Figure 4. Maison pour Tous in Four, France $($ ) CRAterre_Moriset 2019.

This project has strengthened linkages between the concerned actors and has allowed to set operational methodologies and an acceptable legal framework. The success of this project has led to the launching of another pilot project using wattle and daub in 2019 in La Verpillière. Another project is foreseen in 2020 , in the city of Bourgoin-Jallieu. Based on the two former experiences, it proposes numerous technical innovations aiming more efficiency of the building process and further improved accessibility through a potentially high reduction of construction costs for the construction of a $300 \mathrm{~m} 2$ building housing a school kitchen and refectory.

\subsection{Capacity building}

The revival of rammed earth is strongly linked to governmental engagement but also to a vivid construction sector. There are still not enough professionals specialized in rammed earth to maintain the local heritage in good condition and to respond to the demand for new constructions (Figure 5). In recent years, vocational training institutions such as AFPA (National association for professional training of adults) are proposing training modules on rammed earth for the teaching of good practices to young masons (Guillaud, 2014). However, this dynamic needs to be strengthened by fostering collaboration between training institutions and ensuring quality trainings based on important results such as the referential of competences in earthen construction (ECVET Acquis-terre). A better dissemination of the results of recent researches within both the professional sector and training institutions is also needed. The book on rammed earth rehabilitation (Moriset, Joffroy, 2018) which has been published recently, gives detailed informations on rehabilitation techniques and will contribute to the improvement of the quality of the interventions in the public and private spheres.

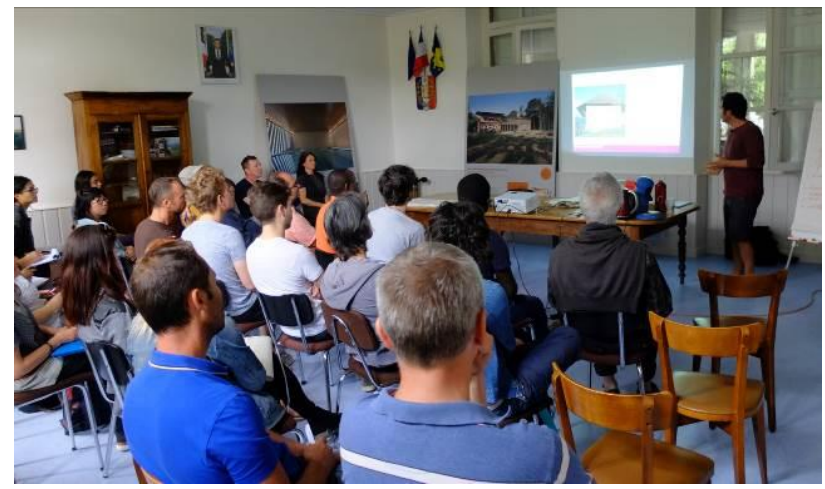

Figure 5. Training on rammed building's diagnostic, France (C) CRAterre_Moriset 2019.

\section{CONCLUSIONS}

This research-action project has highlighted the variety and the quality of rammed earth constructions all over the Region, and the responsibility of local authorities for its proper management in relation to their mandates as well as to the needs and expectations of the inhabitants on their territories.

Some important lessons have been learnt from this research action project. First, the process of revitalisation of earthen architecture is long, a large dissemination strategy on scientific knowledge, general public awareness, technical know-how and good practices were required in the last decades to impulse a positive recognition of earth as a building material, both in its heritage and new construction facets. Secondly, the process of revitalisation requires the full commitment of local authorities which can positively be stimulated by participatory inventory processes, incentive legal frameworks and demonstration projects.

Finally, this research-action has been a very interesting opportunity to re-question some of the activities that had been implemented during the last decades. The strong focus on awareness strategy and pilot demonstration projects have convinced several authorities. Several of them have already embarked on concrete action and are making use of the guide that has been developed to their attention. Still, these local authorities face problems to implement their desired policies.

Now, the step forward is the strengthening of the professional network in order to support the implementation of the local policies on earthen architecture. In fact, there is still a lack of competences within technical services of the local governments, but also a lack of specialised professionals that they could contract or recommend to individual owners for undertaking works. This would clearly support the scaling up of the process.

\section{REFERENCES}

Alex, D. 2012. Petit Guide des architectures en pisé à Lyon. Grenoble: CRAterre éditions, p. 38

Bertin, D., Clémençon, A.S., 1983. L'architecture en terre, un mode de construction urbain ? Le cas de Lyon et sa Banlieue. In Ministère de l'urbanisme et du logement. François Cointeraux 1740-1830. Architecture de terre.

CAUE de l'Ain, 1985. Le bâti ancien des pays de l'Ain, Electricité de France - Pact, Paris-La Défense. p. 135

CRAterre-ENSAG, Asterre, Ecologik, 2013. Communiqué de presse: premier prix national des architectures en terre crue. In Festival Grains d'Isère, du 29 mai au 02 juin 2013. Grenoble : CRATerre-ENSAG, 2013. p. 26.

Guillaud, H., Moriset, S., Gandreau, D., 2014. Continuity of French rammed earth architecture in Restapia.

Guibaud, C., 2005. L'architecture en pisé dans le canton de Boën (Loire). In Situ. Revue des patrimoines. doi:10.4000/insitu.8307

Joffroy, T., Sapere, D., Baldussi, A., 1991. Patrimoine architectural en pisé et en galets en pays de Valloire-Galaure. Repérage de bâtiments typiques et particuliers. GICAM CRATerre-EAG, Saint Vallier, Grenoble. 
Joffroy, T., Rakotomamonjy, B. 2018. Guide à destination des collectivités territoriales pour la réhabilitation et la valorisation du bâti en pisé. CRAterre edition, Villefontaine. p. 100

Mille, E., 2016. Le pisé dans la métropole lyonnaise : si présent, si méconnu: un bâti remarquable à découvrir, valoriser et pérenniser. ENSAG, Grenoble.

Moriset, S. (dir), Joffroy, T.(dir), Béguin, M., Guillaud, H., Misse, A., Pointet, M., 2018. Réhabiliter le pisé: vers des pratiques adaptées. Arles: Actes Sud. 264 p. Coll. Beaux Arts. ISBN 978-2-330-09258-0.

Le Tiec, J., Paccoud, G. 2006. Pisé H2O. De l'eau et des grains pour un renouveau du pisé en Rhône-Alpes. CRAterre edition, Villefontaine. p. 36

Paccoud, P., Chamodot,M., Génis L., Gutiérrez F.,Mille, E, Rakotomamonjy, B., 2017. Maps, actors \& local policies around earth buildings in Auvergne Rhône-Alpes. International Conference on Vernacular Earthen Architecture, Conservation and Sustainability (SOStierra2017), Sep 2017, Valence, Spain. hal-01726667

Rakotomamonjy, B., Moriset, S. et Gandreau, D. 2013. La réhabilitation du pisé en Rhône-Alpes, quelles stratégies ? In Rapport du séminaire du 30 mai 2013 aux Grands Ateliers de l'Isle d'Abeau. Juin 2013. Grenoble : CRATerre éditions, p. 113

Raulin, H., 1977. Dauphiné. Berger-Levrault, Paris.

Royer, C., 1979. Lyonnais. Berger-Levrault, Paris.

Scarato, P., 1984. Inventaire du patrimoine en pisé du département de la Loire. Clermont-Ferrand : Pisé Terre d'avenir.

Studer, D., 2016. Clés de lecture et enjeux de l'architecture de terre en Pays Voironnais. ENSAG, Grenoble. 